\title{
EVALUATION OF INCAPACITY LEVEL IN LEPROSY: A STRATEGY TO SENSITIZE AND TRAIN THE NURSING TEAM
}

\author{
Reinaldo Antonio da Silva Sobrinho ${ }^{1}$ \\ Thais Aidar de Freitas Mathias ${ }^{2}$ \\ Eunice Alves Gomes ${ }^{3}$ \\ Patrícia Barbosa Lincoln ${ }^{4}$
}

Sobrinho RAS, Mathias TAF, Gomes EA, Lincoln PB. Evaluation of incapacity level in leprosy: a strategy to sensitize and train the nursing team. Rev Latino-am Enfermagem 2007 novembro-dezembro; 15(6):1125-30.

The main problems caused by leprosy are physical incapacities. This study evaluated the level of patients' incapacity in treatment and in discharge in 11 municipal districts of the14th Regional of Health of Paraná, at the same time it promoted discussion and qualified nursing professionals of local teams. It was verified that $79.8 \%$ of the population evaluated presented some degree of incapacity and that some of the professionals ignored the evaluation technique. The percentage of patients with incapacity levels I and II was high, fact that corroborates the late diagnosis of cases. The need of a permanent self-care process associated to polichemotherapy and continuous evaluation of new and old cases in order to avoid the illness physical incapacities is highlighted.

DESCRIPTORS: leprosy; inservice training; public health nursing; nursing, team

\section{EVALUACIÓN DEL GRADO DE INCAPACIDAD EN HANSENÍASIS: UNA ESTRATEGIA PARA LA SENSIBILIZACIÓN Y LA CAPACITACIÓN DEL EQUIPO DE ENFERMERÍA}

Los principales problemas originados de la lepra son las inhabilidades. El actual estudio evaluó el grado de incapacidad de los pacientes en tratamiento y los que ya habían sido curados en 11 ciudades de la 14a Regional de la Salud de Paraná, Brasil. Al mismo tiempo, promovió discusión y capacitación de los profesionales de enfermería de los equipos locales. Fue verificado que el $79,8 \%$ de la población evaluada presentó cierto grado de incapacidad y que los profesionales no conocían la técnica de evaluación. Era alto el porcentaje de pacientes con grado de incapacidad I e II, hecho que comprueba la diagnosis retrasada de los casos. Se destaca la necesidad de un proceso permanente de autocuidado, asociado a la poliquimioterapia y la evaluación continua de los casos nuevos y viejos para prevenir las inhabilidades consiguientes de la enfermedad.

DESCRIPTORES: lepra; capacitación en servicio; enfermería en salud pública; equipo de enfermería

\section{AVALIAÇÃO DO GRAU DE INCAPACIDADE EM HANSENÍASE: UMA ESTRATÉGIA PARA SENSIBILIZAÇÃO E CAPACITAÇÃO DA EQUIPE DE ENFERMAGEM}

Os principais problemas decorrentes da hanseníase são as incapacidades físicas. O presente estudo avaliou o grau de incapacidade dos pacientes em tratamento e em alta, em 11 municípios da 14a Regional de Saúde do Paraná, ao mesmo tempo em que promoveu discussão e capacitou os profissionais de enfermagem das equipes locais. Verificou-se que $79,8 \%$ da população avaliada apresentava algum grau de incapacidade e que parte dos profissionais desconhecia a técnica de avaliação. Foi grande a porcentagem de pacientes com grau de incapacidade I e II, fato que corrobora o diagnóstico tardio dos casos. Destaca-se a necessidade de permanente processo de autocuidado, associado à poliquimioterapia e avaliação contínua dos casos novos e antigos para evitar as incapacidades físicas conseqüentes do agravo.

DESCRITORES: hanseníase; capacitação em serviço; enfermagem em saúde pública; equipe de enfermagem

${ }^{1}$ RN, MS in Nursing, Oeste do Paraná State University, Brazil, e-mail: reisobrinho@unioeste.com.br; ${ }^{2}$ PhD in Public Health, Professor, Maringá State University, Brazil ${ }^{3}$ Social Assistant, Sanitarian of the $14^{\text {th }}$ Paranavaí Regional of Health, Brazil; ${ }^{4}$ RN, Family Health Program, Querência do Norte Municipal Government, Brazil 


\section{INTRODUCTION}

$\boldsymbol{H}$ ansen's disease is an infectious contagious disease caused by Mycobacterium leprae, with tropism through the peripheral nerves; the attack on the nerves can knowingly lead to neural damage, change in the sensitive and/or motor function ${ }^{(1)}$. The chronic nature of Hansen's disease is expressed by the mandatory intra-cellular location of the bacillus in the mononuclear system. Every 12 to 21 days, the bacillus undergoes a binary division ${ }^{(2)}$.

A case of Hansen's disease can be defined when the subject presents one or more of the following clinical characteristics: skin injury or injuries with changes in sensitivity, positive sputum smear or attack on the nervous trunk with neural thickening ${ }^{(3)}$.

Considering the spatial distribution of Hansen's disease, it was found to be an endemic problem in developing countries, correlated to socioeconomic, cultural and educational conditions, information access and, essentially, access to healthcare services. The disease is a threat to individual and collective life.

The characteristics of Hansen's disease, such as deformities, used to cause fear among medieval populations ${ }^{(4)}$. Since that age, records of the disease's signs have been found, such as nodes, mutilation, claw hands and hair loss. Hansen's disease, when not timely diagnosed and treated, the disease evolves into disabilities and physical deformities, which lead to decreased working ability, limitation of social life and psychological problems ${ }^{(5)}$. The disability degree is determined through a neurological assessment of the eyes, hands/feet, and its result is expressed in values ranging from 0 (zero) to II (two) ${ }^{(6)}$. The assessment and record of the disabilities are primary activities for the education and promotion of self-care, with a view to preventing the onset of post-discharge disabilities. The neural attack in all forms of Hansen's disease $^{(1)}$

The training of the healthcare team to assess the disability degree must be mainly oriented at professionals from the basic healthcare network, as the Ministry of Health aims to support the decentralization of the diagnosis and treatment to the entire basic network ${ }^{(7)}$.

In a study performed in Buriticupu-MA, it was observed that the lack of qualified personnel for disability degree assessment turned patient care more difficult, suggesting the need to qualify the professionals involved in the program with a view to the correct assessment of the physical disability degree $^{(8)}$. Additionally, the application of basic techniques to prevent disabilities is essential in basic healthcare units, due to the extensive network spread across the national territory, and the units are important weapons in the fight against the main cause of the disease's social stigma ${ }^{(9)}$. The healthcare team's lack of technical qualification may be one of the causes of failure in the suspicion of Hansen's disease, in the follow-up of adverse effects, and in the performance of complementary tests ${ }^{(10)}$. Moreover, the application of basic techniques is also essential because healthcare professionals are not usually alert to diagnose and evaluate the physical disability degree, thus preventing disease sequelae.

Another important fact is that, in Brazil, Hansen's disease and its complications are still a public health challenge, as states such as Mato Grosso, Tocantins, and Espírito Santo showed a prevalence coefficient of $21.51,18.60$ and 4.90 cases $^{(11)}$ per 10,000 inhabitants, respectively, in 2003. Although the state of Paraná shows a prevalence of 2.34 cases per 10,000 inhabitants in the same period (lower than states from other regions), it still has not reach the elimination target established by WHO, which is 1 case for every 10,000 inhabitants. Additionally, it has a higher prevalence among the Southern states, as the prevalence in Rio Grande do Sul was 0.31 cases for 10,000 inhabitants and 1.28 in Santa Catarina in 2003. When considering the prevalence per micro region, high percentages are found, like in the $14^{\text {th }}$ Health Region of Paraná, with 4.83 cases per 10,000 inhabitants ${ }^{(11)}$.

It is emphasized that all clinical forms of Hansen's disease can cause physical disabilities. According to the Ministry of Health, all new cases must be evaluated at the beginning of the treatment and at the moment of discharge ${ }^{(9)}$. The assertions above led to the proposal of this work, in addition to the need to classify the physical disability degree, due to deformities that may be caused by Hansen's disease, which motivated the qualification of nursing professionals to evaluate the disability degree in patients enrolled in and discharged from the program.

In this sense, the purpose of this study was to evaluate the disability degree in people enrolled in and discharged from the National Hansen's disease Control Program of the Ministry of Health, living in the 14th Health Region of Paraná, and to use this 
activity as a strategy to sensitize and qualify nursing professionals to intervene in the care process of patients with Hansen's disease with a view to preventing physical disabilities and promoting selfcare. This action was part of activities to control and eliminate Hansen's disease, proposed and coordinated by the Paraná State Department of Health.

\section{METHOD}

The $14^{\text {th }}$ Health Region is one of the politicaladministrative regions of the State Department of Health-PR, composed by 28 cities, with approximately 328 thousand inhabitants and headquartered in Paranavaí. This city is located in the Northwest, at about $540 \mathrm{~km}$ from the state capital, with 78,693 thousand inhabitants ${ }^{(12)}$. Its economy is based on poultry, cassava and citrus fruits, and the city constitutes an economic and regional health pole. The city has only two hospitals, one of which provides high-complexity services, a central Health Informatics Nucleus, ten basic health units (UBS), the Regional Specialties Association, a hemonucleus, a hemodialysis and radiology clinic and bio-analysis labs.

For the physical disability evaluation and health team qualification, 11 cities from the 14th Region were chosen, which displayed the highest Hansen's disease detection rates. The disability degree was analyzed according to gender, age and program record status.

The evaluation of the patient's neural functions, complications and self-care guidance, as well as the physical disability degree classification were performed according to Ministry of Health ${ }^{(3)}$ standards, which use the following criteria: degree 0 (zero), when there is no neural impairment in the eyes, hands or feet; degree I (one), corresponding to a decrease or loss of sensitivity and degree II (two), indicating the presence of disabilities and deformities, such as lagophthalmus, claws, bone reabsorption, hands and feet deformity, among others ${ }^{(9)}$.

The evaluation work of disability degrees in each of the 11 cities, was performed together with the local healthcare teams for sensitization, training and guidance in the realization of the disability prevention activities, with a view to the reorientation of strategies and care modes, treatment and followup of individual and collective health ${ }^{(13)}$.
One representative from the 14 th Paraná Health Region, one nurse teaching at the School of Nursing of the Faculdade Intermunicipal do Noroeste do Paraná (Facinor), one nursing aid of the Municipal Department of Health of Loanda-PR, participated in the organization of activities and gave advice and training, in addition to students from the Facinor School of Nursing. Thirteen nurses and 20 nursing aids participated as trainees. The activities were performed in November and December, 2003.

The visits were scheduled in each city and the local nursing teams joined the patients to participate in the action. The team evaluated each patient, individually, in his/her city of origin, with patients from Inajá-PR (11), Loanda-PR (19), Marilena-PR (8), Paranavaí-PR (18), Porto Rico-PR (3), Querência do Norte-PR (15), Santa Cruz de Monte Castelo-PR (5), Santa Mônica-PR (5), Santo Antonio do Caiuá-PR (6), Tamboara-PR (4) and Terra Rica-PR (5), totaling 99 patients.

The cities' nursing teams were qualified by demonstrating the disability evaluation steps in the patients. The intention was to perform the visit with the presence of local professionals in the care room, as this would provide for the patient's integration with the work team and local nursing professionals, identifying the problems, indicating specific treatment and confirming the professionals' responsibilities towards the patients, encouraging them to continue treatment. Attempts were made to show the technique, details of the inspection checklist, the correct use of simple instruments needed for the procedure, sensitization about the importance and need for intervention, trying to offer knowledge in order to acquire skills by assessing the patient at the moment of the diagnosis, at discharge and periodically after discharge. This was a punctual strategy to qualify the professionals and, due to its duration, cannot be configured as a continuous educational process ${ }^{(14)}$.

The study was submitted to the Ethics Committee at Maringá State University-PR, in accordance with Resolution $196 / 96$ by the National Health Council. The people involved received the necessary information about the research and were asked to give their written consent.

\section{RESULTS}

Of the 99 people evaluated, $66.7 \%$ were male, $61.6 \%$ were under treatment, and $38.3 \%$ were discharged from the National Hansen's disease Control 
Program. The most frequent age group was 50 years or older $(52.5 \%)$, followed by the range from 20 to 49 years $(38.4 \%$ ) (Tables 1 and 2 ). The youngest person was 10 years old and the oldest 87 years.

Regarding the disability degree, $20.2 \%$ were classified as physical disability degree $0,41.4 \%$ degree I and $38.4 \%$ degree II, with $34.4 \%$ of the people under treatment and $44.7 \%$ of those already discharged from the program showing the highest disability degree (Table 1 ). It is remarkable that, among the 99 people evaluated, 86 (87\%) had not been previously assessed.

Table 1 - Distribution of people according to disability degree and program enrollment, $14^{\text {th }}$ Health Region, PR, 2003

\begin{tabular}{ccccccc}
\hline \multirow{2}{*}{ Degree } & \multicolumn{2}{c}{ Under Treatment } & \multicolumn{2}{c}{ Discharged } & \multicolumn{2}{c}{ Total } \\
& $\mathbf{N}^{\mathbf{0}}$ & $\%$ & $\mathbf{N}^{\circ}$ & $\%$ & $\mathbf{N}^{\circ}$ & $\%$ \\
\hline 0 & 11 & 18,0 & 9 & 23,7 & 20 & 20,1 \\
I & 29 & 47,6 & 12 & 31,6 & 41 & 41,4 \\
II & 21 & 34,4 & 17 & 44,7 & 38 & 38,4 \\
\hline Total & $\mathbf{6 1}$ & $\mathbf{1 0 0}$ & $\mathbf{3 8}$ & $\mathbf{1 0 0}$ & $\mathbf{9 9}$ & $\mathbf{1 0 0}$ \\
\hline
\end{tabular}

\section{DISCUSSION}

In this work, as well as in other studies ${ }^{(10,15)}$, an important percentage of cases was found among people in the productive phase of life and most of them $(79,8 \%)$ showed a disability degree of I or II (Table 2). During the evaluation, a relevant number of lower limb sequelae (data not shown) was found, especially in the feet, such as dryness, fissures, claws, extensive loss of sensitivity, plantar perforating wounds, reabsorption, feet deformity and mutilation, particularly in discharged patients. This information indicates the service's difficulties in the control strategy of Hansen's disease and its complications in the study region, showing late case diagnosis, due to the presence of disabling sequelae ${ }^{(8)}$.

The results of this study are similar to those found in a research performed in Buriticupu-MA, which concluded that, at the end of the treatment recommended by the Ministry of Health, most cases had not been assessed ${ }^{(8)}$

One action that might prevent and even reverse physical sequelae is the assessment of disabilities at the beginning of treatment because, if the patient shows impaired nerves, the risk of developing disabilities is higher. Therefore, the Hansen's disease control programs must be judicious in their initial evaluation ${ }^{(1)}$.

Of the 99 people evaluated, 5 were younger than 15 (Table 2). The appearance of young patients shows continuity in the disease transmission process, and this variable indicates an area with non-diagnosed reservoirs ${ }^{(5,10)}$.

Every year, about 3,000 new cases of Hansen's disease are recorded in Brazil in children under 14. In the state of Paraná, in 2004, for every 100 adults diagnosed, four cases were in children ${ }^{(16)}$. The detection rate among patients under 15 in a study performed in the Vale do Jequitinhonha-MG was 2.12/10,000 inhabitants in 1998 and 1.98/10,000 inhabitants in 2002, considered high for the age level. The detection rate in the population younger than 15 practically follows the general detection rate of the disease ${ }^{(5)}$.

Until 1920, the main control of Hansen's disease consisted in the patients' isolation from the healthy population. In 1926, the acting Governor of the State of Paraná signed the decree to regulate the compulsory isolation and regulation of the Leprosário São Roque. It was only in 1957, in the Northwest of Paraná, specifically in the city of Maringá, that the first outpatient clinic for Hansen's disease patients was created, which was part of the former National Leprosy Division ${ }^{(17)}$. Currently, the primary goal of the national Hansen's disease control policy is the elimination of the disease as a public health problem, requiring the decrease of prevalence to one or less than one case for every 10,000 inhabitants. To make this happen, early case diagnosis is essential, thus preventing not only transmission, but also physical disabilities. Other priorities are the evaluation of the physical disabilities, special attention to the diagnosis of cases in patients younger than 14 and the qualification of healthcare professionals, based on the population's health needs, with the purpose of transforming professional practices ${ }^{(13)}$.

Table 2 - Distribution of people evaluated by disability degree according to gender and age, 14th Health Region, PR, 2003

\begin{tabular}{|c|c|c|c|c|c|c|c|c|}
\hline \multicolumn{9}{|c|}{ Male } \\
\hline \multirow{2}{*}{$\begin{array}{c}\text { Degree } \\
\text { Age }\end{array}$} & \multicolumn{2}{|c|}{0} & \multicolumn{2}{|c|}{ I } & \multicolumn{2}{|c|}{ II } & \multicolumn{2}{|c|}{ Total } \\
\hline & $\mathbf{N}^{\circ}$ & $\%$ & $\mathrm{~N}^{0}$ & $\%$ & $\mathbf{N}^{\circ}$ & $\%$ & $\mathbf{N}^{\circ}$ & $\%$ \\
\hline $10-14$ & 1 & 1.5 & - & - & - & - & 1 & 1.5 \\
\hline $15-19$ & 1 & 1.5 & 1 & 1.5 & - & - & 2 & 3.0 \\
\hline $20-49$ & 4 & 6.0 & 14 & 21.2 & 9 & 13.6 & 27 & 40.8 \\
\hline 50 and + & 1 & 1.5 & 12 & 18.1 & 23 & 34.8 & 36 & 54.4 \\
\hline Total & 7 & 10.5 & 27 & 40.8 & 32 & 48.4 & 66 & 100 \\
\hline \multicolumn{9}{|c|}{ Female } \\
\hline $10-14$ & 2 & 6.0 & 2 & 6.0 & - & - & 4 & 12.0 \\
\hline $15-19$ & 2 & 6.0 & - & - & - & - & 2 & 6.0 \\
\hline $20-49$ & 4 & 12.1 & 5 & 15.1 & 2 & 6.0 & 11 & 33.2 \\
\hline 50 and + & 5 & 15.1 & 7 & 21.2 & 4 & 12.0 & 16 & 48.3 \\
\hline Total & 13 & 39.2 & 14 & 42.3 & 6 & 18.0 & 33 & 100 \\
\hline \multicolumn{9}{|c|}{ Total } \\
\hline $10-14$ & 3 & 3.0 & 2 & 2.0 & - & - & 5 & 5.0 \\
\hline $15-19$ & 3 & 3.0 & 1 & 1.0 & - & - & 4 & 4.0 \\
\hline $20-49$ & 8 & 8.0 & 19 & 19.1 & 11 & 11.1 & 38 & 38.2 \\
\hline 50 and+ & 6 & 6.0 & 19 & 19.1 & 27 & 27.2 & 52 & 52.3 \\
\hline Total & 20 & 20.0 & 41 & 41.2 & 38 & 38.3 & 99 & 100 \\
\hline
\end{tabular}


The National Hansen's Disease Control Program included a number of essential actions, including the prevention and decrease of physical damage and health education, with its programming under the responsibility of all levels: local, municipal, state and federal, which must also be based on epidemiological indicators ${ }^{(3)}$.

Regarding the trained professionals, good information incorporation was observed, as well as sensitization to the problem and technical ability to deliver care to the patients in their field of action, as determined by the Ministry of Health in the search for integral care through the basic care strategy ${ }^{(13)}$.

Qualification is a continuous process. However, the rotation of healthcare personnel, especially in the Family Health Program, is an aggravating issue in the continuity of Hansen's disease patient care. To face this difficulty, a good strategy adopted by the state of Rio de Janeiro was the qualification of permanent instructors and knowledge multipliers ${ }^{(7)}$. Moreover, professionals taking specialization or advanced courses get a deeper understanding of the importance of the permanent education process ${ }^{(18)}$, which is strategic for the education and learning of workers in the organization of the nursing work process ${ }^{(19)}$.

It can be concluded that the evaluation and prevention of physical disabilities cannot be dissociated from polychemotherapy treatment, as this association, together with other specific interventions, shows the magnitude of Hansen's disease control.

During the patients' evaluation together with the nursing team in each city, it was observed that many professionals did not know the disability degree evaluation and classification technique and its importance as a prevention strategy, a fact evidenced by the small number of patients evaluated by the local health services and the relevant number of patients with sequelae.

One city had not decentralized the diagnosis and treatment of Hansen's disease to the UBS yet, and was using the referral site to treat patients. Similarly, among four cities analyzed in Mato Grosso in 1997, only one performed the physical disability degree evaluation and most of the patients seeking care already had some disease sequela ${ }^{(15)}$.

Thus, permanent education work in the cities is required, which is the space where most healthcare actions and healthcare team work occur ${ }^{(13)}$, to promote discussions and to check the trained professionals' adherence to physical disability evaluation and classification in their respective patients as a routine activity. The disability degree evaluation of new cases through dermato-neurological examination is essential, as the patient may show affected peripheral nerves or physical disability at the moment of the diagnosis ${ }^{(1)}$.

The health promotion activities must be started at the moment the patient initiates the treatment and all team professionals must be qualified to receive the needy patients within an overall, holistic view, using a clarifying language that reinforces or reformulates their knowledge. In this sense, nursing is unquestionably important, in view of its responsibility for holistic care, which is the focus of nursing. Technical conditioning, the performance of procedures and the cognitive are part of care, but they should not constitute a mere task or be carried out mechanically ${ }^{(20)}$.

When performing the disability degree evaluation, each step must be strictly informed, discussed, and clarified to the patients, as the purpose is for them to learn the simple disability prevention techniques and repeat them at home on a daily basis, thus avoiding the sequelae. Thus, the patient acquires knowledge, skills and appropriate professional support, and is also stimulated towards self-care. The health education process designed for people with chronic diseases can facilitate both learning for healthcare promotion and the encouragement of new social relationship practices.

The PRECEDE (Preceding, Reinforcing, Enabling Causes in Educational Diagnosis And Evaluation) model points to the complexity of selfcare, which at first may seem simple. This model shows the factors that facilitate or hinder appropriate self-care, as these are many times considered ordinary by healthcare professionals ${ }^{(6)}$.

Successful elimination strategies for Hansen's disease and other transmittable diseases consist in equipping the healthcare services, and especially preparing the healthcare professionals to change the epidemiological condition of these diseases in the country, providing them with qualification using theorypractice, education, service and community interaction techniques as an efficient methodological instrument. Therefore, the pedagogical ability needs to be decentralized and disseminated "into the healthcare service", i.e., among the workers, managers and teachers with social control in health - permanent education in health ${ }^{(21)}$.

For Brazil to eliminate the disease as a public health problem, health services need professionals with the ability to work in team, interacting with people and social segments, collecting and processing information 
by means of communication, besides using their skills and qualifications in daily work ${ }^{(6,22)}$. Finally, for the nurse to develop training sessions with the nursing team, in addition to the pedagogical strategy, scientific and technical approach, other context determinants are required, including ethics and humanization.

\section{ACKNOWLEDGEMENTS}

To the State and Regional Coordination of Hansen's Disease Control and Elimination of the State of Paraná and the NGO-NLR Netherlands Leprosy Relief - Amsterdam, The Netherlands.

\section{REFERENCES}

1. Pimentel MIF, Nery JAC, Borges E, Gonçalves RR, Sarno EN. O exame neurológico inicial na hanseníase multibacilar: correlação entre a presença de nervos afetados com incapacidades presentes no diagnóstico e com a ocorrência de neurites francas. Anais Bras Dermatol 2003 setembro - outubro; 78(5):561-8.

2. Goulart IMB, Penna GO, Cunha G. Imumopatologia da hanseníase: a complexidade dos mecanismos da resposta imune do hospedeiro ao Micobacterium leprae. Rev Soc Bras Med Trop 2002 julho-agosto; 35(4):365-75.

3. Ministério da Saúde (BR). Departamento da Atenção Básica. Guia para o controle da hanseníase. Brasília (DF): Ministério da Saúde; 2002.

4. Cunha AZ. Hanseníase, aspectos da evolução do diagnóstico, tratamento e controle. Rev Ciência \& Saúde Coletiva 2002 maio; 7(2):235-42.

5. Lana FCF, Amaral EP, Franco MS, Lanza FM. Estimativa da prevalência oculta da hanseníase no Vale do Jequitinhonha MG. Rev Min Enferm 2004 abril-junho; 8(2):295-300.

6. Ministério da Saúde (BR). Área Técnica de Dermatologia Sanitária. Manual de prevenção de incapacidades. Brasília (DF): Ministério da Saúde; 2001.

7. Moreira TA. Panorama sobre a hanseníase: quadro atual e perspectivas. Hist Cienc Saude - Manguinhos 2003 abril; 10 (Supl 1): 291-7.

8. Aquino CMD, Santos SJ, Costa LMJ. Avaliação do programa de controle da hanseníase em um município hiperendêmico do Estado do Maranhão Brasil. Cad Saúde Pública 2003 janeiro - fevereiro; 19(1):119-25.

9. Ministério da Saúde (BR). Área Técnica de Dermatologia Sanitária. Hanseníase atividades de controle e manual de procedimentos. Brasília (DF): Ministério da Saúde; 2004.

10. Goulart IMB, Arbex GL, Carneiro MH, Rodrigues MS, Gadia R. Efeitos adversos da poliquimioterapia em pacientes com hanseníase: um levantamento de cinco anos em um Centro de Saúde da Universidade Federal de Uberlândia. Rev Soc Bras Med Trop 2002 setembro - outubro; 35(5):453-60.

11. Secretaria de Estado de Saúde Paraná [homepage na Internet]. Curitiba: Secretaria de Estado de Saúde Paraná; [Acesso em 2006 janeiro 06]. Estratégias de eliminação da hanseníase no estado do Paraná.[2 telas]. Disponível em :http://www. saude.pr.gov.br/ hanseniase/index.html 12. Fundação IBGE [homepage Internet]. Rio de Janeiro: Fundação IBGE; [Acessado em 2006 janeiro 25]. Informações estatísticas e geocientíficas. [2 telas]. Disponível em: http:/ /www.ibge.gov.br/cidadesat/default.php
13. Ministério da Saúde (BR).Secretaria de Gestão do Trabalho e da Educação em Saúde. Políticas de educação e desenvolvimento para o SUS. Caminhos para a educação permanente em saúde. Brasília (DF): Ministério da Saúde; 2004.

14. Haddad OJ, Roschke MAC, Davini, MC. Educación permanente de personal de salud. Washington: OPS; 1994. 15. Munhoz JR, Fontes CJF, Meirelles SMP. Avaliação do programa de hanseníase em municípios Matogrossenses. Rev Saúde Pública 1997 junho; 31(3):282-7.

16. Ministério da Saúde (BR) [homepage na Internet]. Brasília: Ministério da Saúde; [Acesso em 2005 Dezembro 06]. Serviço de Vigilância Sanitária: Crianças com hanseníase.[2 telas] Disponível em: http://dtr2001.saude.gov.br/svs/epi/ hanseniase/PR_2005.pdf

17. Junqueira TB. Hanseníase e migração no município de Maringá - Paraná: 1957 a 1997. [dissertação]. Ribeirão Preto (SP): Escola de Enfermagem de Ribeirão Preto /USP; 1998. 18. Silva MP, Esteves TMB, Rocha GWF. Avaliação do curso de especialização em enfermagem nas doenças infecciosas, na FIOCRUZ (1997-1999). Rev Latino-am Enfermag 2004 março-abril; 12(2):265-70.

19. Ricaldoni CAC, Sena RR. Educação Permanente: uma ferramenta para pensar e agir no trabalho de enfermagem. Rev Latino-am Enfermagem 2006 novembro-dezembro; 14(6): 847-2.

20. Waldow VR. O cuidado na saúde, as relações entre o eu, o outro e o cosmos. Petrópolis (RJ): Vozes; 2004.

21. Ceccim RB. Educação Permanente em Saúde: descentralização e disseminação de capacidade pedagógica na saúde. Rev Ciência Saúde Coletiva 2005 janeiro; 10(4):975-86.

22. Sobrinho RAS, Gomes EA, Mathias TAF. Hanseníase: A Importância da Integração entre Ensino e Serviço. $1^{\circ}$ Congresso Internacional de Saúde; 2005 outubro 05-08; Maringá; Brasil; 2005. 